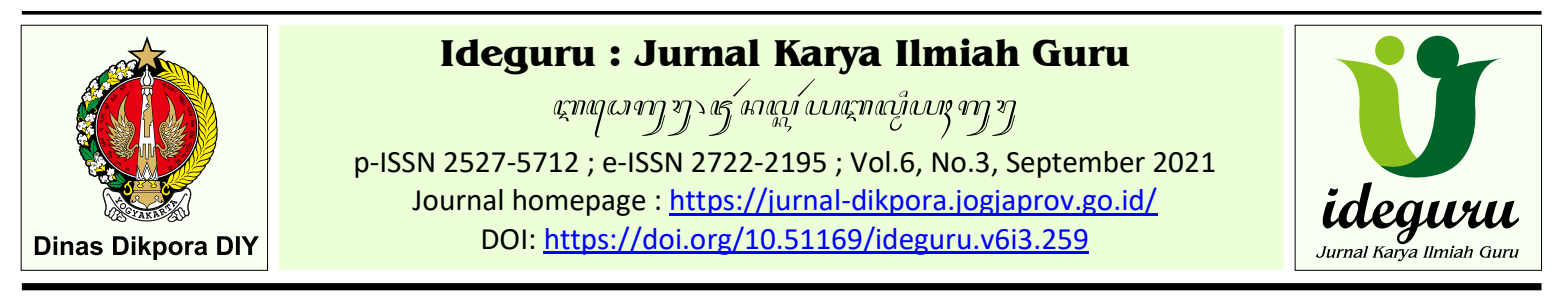

Artikel Penelitian - Naskah dikirim: 16/03/2021 - Selesai revisi: 25/07/2021 - Disetujui: 27/07/2021 - Diterbitkan: 01/09/2021

\title{
Peningkatan Motivasi dan Hasil Belajar Geografi melalui Model Cooperative Learning Tipe Group Investigation
}

\author{
Suyatinah \\ SMA Negeri 1 Banguntapan, Bantul, Daerah Istimewa Yogyakarta, Indonesia \\ suyatinahmitro@gmail.com
}

\begin{abstract}
Abstrak: Penelitian ini bertujuan untuk mengetahui penerapan Model Pembelajaran Cooperative Learning tipe Group Investigation untuk meningkatkan motivasi dan hasil belajar Geografi siswa Klas XII IPS 2 SMA N 1 Banguntapan Tahun Ajaran 2019/ 2020 yang berjumlah 31 orang, yang terdiri dari 12 siswa pria dan 19 siswa wanita. Jenis tindakan yang dipilih adalah Penelitian Tindakan Kelas, yang dilaksanakan dari bulan Juli 2019 sampai Oktober 2019. Objek Penelitian adalah Motivasi dan Hasil Belajar siswa. Langkah-langkah penelitian meliputi perencanaan, pelaksanaan, observasi dan refleksi, dilaksanakan dalam 2 siklus yang masing-masing siklus meliputi 2 kegiatan pembelajaran dan 1 kegiatan ulangan. Pengumpulan data dilakukan melalui dokumentasi, angket, observasi, dan test tertulis. Data yang diperoleh dianalisa secara kuantitatif dalam bentuk prosentase, yang kemudian didiskripsikan dan diambil kesimpulan. Pelaksanaan pembelajaran yang menggunakan model Cooperative Learning tipe Group Investigation dapat diterima baik oleh siswa, menumbuhkan sikap positif untuk saling berkolaborasi dalam proses pembelajaran, ada proses tutor teman sebaya, berdampak pada meningkatnya motivasi belajar siswa dari 88,60\% tergolong adekuat pada siklus I, menjadi 93,75\% tergolong bagus pada siklus II. Penerapan model pembelajaran ini juga dapat meningkatkan hasil belajar pada siswa klas XII IPS 2 SMA Negeri 1 Banguntapan Tahun Ajaran 2019/2020, yang terlihat pada meningkatnya ketuntasan belajar dari $80 \%$ pada siklus I dan 90,32\% pada siklus II. Guru sebaiknya selalu berinovasi dengan menggunakan model pembelajaran yang bervariasi agar siswa selalu motivasi belajar, sehingga hasil belajarnya akan meningkat.
\end{abstract}

Kata kunci: motivasi belajar; hasil belajar; cooperative learning; group investigation.

\section{Increasing Motivation and Learning Outcomes of Geography through Cooperative Learning Model Type Group Investigation}

\begin{abstract}
The goal of this practical research is to find out the step of applying the Cooperative Learning model, type Group Investigation. As well as the effect of the model in increasing motivation and learning result on geography subject of XII IPS 2 class of SMA Negeri 1 Banguntapan in the academic year of 2019/2020. The type of practical used is Classroom reseach. The study was conducted from July until October 2019, motivation and learning result as the research objective. The research stages include planning, implementation, observation, and reflection, which were implemented in 2 cycles. Each of the cycles covering 2 learning activities and 1 exam. Data were collected through documentation, questionnaires, observations, and written tests. The obtained data were analyzed quantitatively in the form of percentages, which were then described and conclusions drawn. The implementation of learning that uses the Cooperative Learning model of the Group Investigation type can be well received by students, fosters a positive attitude to collaborate in the learning process, there is a peer tutoring process, that has an impact on students learning motivation from $88,60 \%$ is quite adequate in the first cycle, becoming $93.75 \%$ is classified as good in the second cycle. The application of this learning model can also improve learning outcomes for students of class XII IPS 2 of SMA Negeri 1 Banguntapan for the 2019/2020 academic year, which can be seen in learning completeness of $80 \%$ in cycle I and $90.32 \%$ in cycle II. Teachers should constantly innovate by using varied learning models so that students are always motivated to learn, and the learning outcomes will increase.
\end{abstract}

Keywords: motivation to learn; learning outcome; cooperative learning; group investigation. 


\section{Pendahuluan}

Guru merupakan profesi yang membanggakan karena mengemban tugas mencerdaskan anak bangsa. Begitu pentingnya peran tersebut, maka dalam menjalankan tugasnya, guru dituntut mengikuti aturan minimal proses pembelajaran yang dikenal dengan Standar Proses Pendidikan. Jika guru mampu melaksanakan tugasnya sesuai dengan aturan tersebut, maka tujuan pembelajaran dapat diraih, harapannya peningkatan kualitas lulusan dapat tercapai dengan baik.

Geografi merupakan ilmu yang mempelajari gejala alam (litosfer, pedosfer, hidrosfer, atmosfer, biosfer) dan manusia, serta interaksi antara keduanya. (Silabus Mata Pelajaran geografi 2019).

Obyek kajian geografi adalah hal- hal yang nyata/ kontekstual dipermukaan bumi. Banyak konsep berupa istilah- istilah yang harus dipahami. Jika model pembelajaran yang digunakan masih didominasi ceramah, membuat siswa jenuh, bosan, bahkan bisa merasa monoton. (Bobbi, dkk, 2010: 68). Kondisi ini bisa berdampak pada rendahnya motivasi siswa dalam mengikuti pembelajaran.

Sebagai motivator, guru harus mampu membangkitkan motivasi belajar peserta didik. Motivasi adalah tenaga pendorong atau penarik yang menyebabkan adanya tingkah laku kearah suatu tujuan tertentu. Motivasi dapat menyebabkan terjadinya perubahan energi pada diri seseorang, baik yang menyangkut kejiwaan, perasaan, dan emosi, dan kemudian mendorong seseorang melakukan suatu tindakan. (Mulyasa, 2008: 58).

Motivasi yang berasal dari dalam diri siswa dikenal dengan motivasi intrisik, seperti rasa tanggung jawab sebagai pelajar, keinginan mendapatkan prestasi maksimal, ingin maju, dll, namun jika kekuatan pendorong untuk melakukan kegiatan belajar berasal dari luar diri siswa dikenal dengan motivasi ekstrisik, seperti penyajian pembelajaran yang menarik, pemberian nilai, pujian, apresiasi dari guru. (Syaiful Bahri, 2000 : 185). Siswa yang memiliki motivasi belajar tinggi tampak pada sikap dan perilakunya, misalnya memperhatikan pelajaran yang disampaikan guru dengan seksama, rajin belajar, rajin mengerjakan tugas, mau membaca untuk mencari bahan- bahan untuk memahami suatu topik (Stevani, 2016: 311).

Guru harus selalu berusaha untuk disenangi siswa ampuannya, baik terkait penampilannya, perilakunya maupun penyajian mata pelajaran yang diajarkannya. Perasaan senang tersebut diharapkan dapat membawa pengaruh baik terhadap kelancaran proses pembelajaran, yang selanjutnya akan meningkatkan ketercapaian peningkatan prestasi siswa (Zainuddin, 2017: 340).

Prestasi belajar/ hasil belajar siswa diukur dari kemampuan siswa dalam menguasai materi pelajaran yang diberikan guru, juga ketrampilanketrampilan mengenai mata pelajaran yang telah diberikannya. (Syaiful Bahri, 2000: 210). Sedangkan menurut Sunarti hasil belajar merupakan data yang menunjukkan pencapaian belajar peserta didik (Sunarti, 2008: 3).

Prestasi belajar yang optimal hanya bisa dicapai jika siswa memiliki motivasi tinggi dalam mengikuti proses pembelajaran dan guru mampu menyajikan proses pembelajaran yang efektif dan menyenangkan.

Proses Pendidikan yang sesuai dengan standar nasional adalah Proses Pembelajaran yang harus mampu menghadirkan komunikasi yang intens, komunikasi yang aktif antara siswa dengan guru, dan terutama antara siswa dengan siswa, sehingga suasana belajar menyenangkan, harapannya mampu menumbuhkan inspirasi, rasa ingin tahu siswa, ide, kreativitas, dan kemandirian sesuai dengan bakat, minat, dan perkembangan siswa, baik perkembangan fisiknya maupun psikologisnya. (Widarwati, 2009: 6). Untuk itu, Guru harus selalu memberikan motivasi yang bervariasi kepada siswanya, karena jika siswa tidak memiliki motivasi belajar, mereka akan menjalani proses pembelajaran yang kurang bermakna dan tentunya prestasi hasil belajar tidak tercapai secara maksimal. Penjelasan tersebut menunjukkan keterkaitan erat antara motivasi belajar, proses belajar, dan hasil belajar.

Kondisi di lapangan yang sering dihadapi guru adalah pencapaian hasil belajar siswa yang jauh dari harapan. Hal ini terjadi pada Kelas XII IPS 2 SMA N 1 Banguntapan Tahun Pelajaran 2019/ 2020, yang merupakan salah satu kelas yang perolehan nilai mata pelajaran Geografi yang rendah. Hasil penilaian harian KD 3.1. tentang Wilayah dan Perwilayahan, perolehan rerata nilainya 59. Nilai tersebut masih jauh dibawah kriteria minimal yang ditetapkan, yaitu 68. Untuk mengatasi kondisi tersebut, guru bermaksud melibatkan siswa dalam pembelajaran kelompok dengan tipe Group Investigation / Investigasi Kelompok pada pembelajaran di kelas tersebut.

Model pembelajaraan tersebut diatas menerapkan pengelompokan siswa secara heterogen, dalam hal jenis kelamin, agama, kemampuan akademik, dll. Siswa akan saling berinteraksi untuk menyelesaikan tugas dari 
guru, ada proses diskusi, saling berpendapat, saling menghargai pendapat teman lainnya, dan memecahkan permasalahan secara bersama.

Siswa yang memiliki kemampuan akademik yang berbeda akan digabung dalam satu kelompok. Harapanya siswa yang memiliki kemampuan akademik tinggi dapat berperan sebagai penggerak / motivator bagi teman lainnya yang kemampuan akademiknya sedang atau rendah. Disini akan terjadi proses tutor teman sebaya, penularan kepintaran, sehingga diharapkan mampu meningkatkan hasil belajar siswa (Zainuddin, 2017: 334).

Proses belajar seperti ini mendatangkan manfaat bagi berbagai kelompok siswa yang memiliki kemampuan akademik berbeda. Bagi siswa dengan kelompok akademik sedang dan rendah, akan termotivasi untuk aktif dalam menguasai materi pelajaran, sedangkan siswa dengan kemampuan akademik tinggi akan semakin meningkat kemampuan akademisnya karena peranannya sebagai tutor membutuhkan pemikiran yang mendalam terhadap bahan ajar. (Jamil Suprihatiningrum, 2014: 127)

Rangkaian penerapan Model pembelajaraan kooperatif tipe Group Investigation (Investigasi Kelompok) adalah: 1) Memilih topik dan membagi siswa ke dalam beberapa kelompok secara heterogen, 2). Membagi tugas dalam kelompok; 3). Melaksanakan investigasi, siswa secara berkelompok menggali informasi dari berbagai sumber melalui diskusi kelompok untuk mengerjakan tugas investigasi, anggota kelompok menuliskan hasil diskusi pada lembar kerja siswa; 4). Membuat laporan akhir sebagai bahan diskusi; 5) Presentasi kelompok secara bergantian, kelompok lainnya bertanya/ menanggapi, untuk selanjutnya dijawab oleh kelompok presenter, seluruh siswa merangkum semua materi yang dibahas; 6) Evaluasi, dilakukan bersama antara siswa dan guru untuk medapatkan umpan balik. (Slavin, 2009: 218220)

Permasalahan yang diangkat pada Penelitian ini yang adalah: 1). Bagaimana penerapan Model Cooperative Learning tipe Group Investigation dalam pembelajaran, 2). Bagaimana pengaruh Model Cooperative Learning tipe Group Investigation dalam meningkatkan motivasi belajar siswa dan 3). Bagaimana pengaruh Model Cooperative Learning tipe Group Investigation dalam meningkatkan hasil belajar Geografi siswa kelas XII IPS 2 SMA Negeri 1 Banguntapan Tahun Ajaran 2019/2020.

Tujuan yang diharapkan dari Penelitian ini adalah: 1). Mengetahui penerapan Model Cooperative Learning tipe Group Investigation dalam pembelajaran, 2). Peningkatan motivasi belajar siswa dan 3). Peningkatan hasil belajar geografi siswa kelas XII IPS 2 SMA Negeri 1 Banguntapan Tahun Ajaran 2019/2020 melalui penerapan Model Cooperative Learning tipe Group Investigation.

Penelitian ini diharapkan bermanfaat untuk: 1). Meningkatkan pengetahuan dan pemahaman guru terhadap Model Cooperative Learning tipe Group Investigation, 2). Meningkatan motivasi belajar siswa, 3). Meningkatan hasil belajar geografi siswa kelas XII IPS 2 SMA Negeri 1 Banguntapan Tahun Ajaran 2019/2020 melalui penerapan Model Cooperative Learning tipe Group Investigation.

Penelitian Tindakan Kelas yang relevan dengan penerapan metode pembelajaran tersebut dilakukan oleh Suranten, dimana terjadi peningkatan tingkat ketuntasan dari $51 \%$ pada siklus I menjadi $69 \%$ pada siklus II. (Suranten, 2019: 40). Selain itu, hasil penelitian tindakan kelas Alfi Syukriyati juga menunjukkan hal yang sama, dimana terjadi peningkatan ketuntasan hasil belajar siswa dari $34,78 \%$ pada siklus I menjadi 63,64\% pada siklus II. (Syukriyati, 2015: 61).

\section{Metode Penelitian}

Penelitian ini merupakan Penelitian Tindakan Kelas yang dilaksanakan selama empat bulan mulai bulan Juli berupa kegiatan perencanaan, dilanjutkan pelaksanaan tindakan yang dilaksanakan pada bulan AgustusSeptember, Seminar dan pelaporan di bulan Oktober. Tempat penelitian dilaksanakan di SMA Negeri 1 Banguntapan Bantul yang ber alamat di Ngentak, Baturetno, Banguntapan, Bantul. Subyek penelitian tindakan kelas ini adalah siswa kelas XII IPS 2 SMA N 1 Banguntapan Tahun Ajaran 2019/2020 yang berjumlah 31 orang, yang terdiri dari 12 pria dan 19 wanita.

Menurut Kammis dan Taggat dalam Wasisto (2018: 34), langkah-langkah penelitian tindakan kelas digambarkan pada gambar 1 berikut.

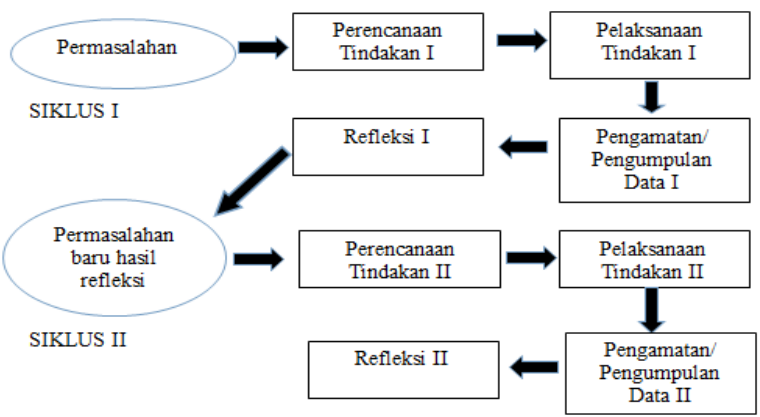

Gambar 1. Langkah-langkah Penelitian Tindakan Kelas (PTK) 
Setiap siklus dalam kegiatan Penelitian Tindakan Kelas yang dilaksanakan meliputi 4 tahap, yaitu perencanaan, pelaksanaan, observasi, dan refleksi. Kegiatan yang dilakukan pada tahap perencanaan meliputi penyusunan administrasi pembelajaran. Pada tahap pelaksanaan, guru mengajar - siswa belajar, aktivitas siswa dan guru diobservasi. Hasil pengamatan digunakan sebagai refleksi pada siklus berikutnya. Jika sudah terjadi peningkatan motivasi belajar dan hasil belajar dari siklus I ke siklus II, maka siklus dihentikan. Namun jika belum menunjukkan peningkatan yang signifikan, maka dilanjutkan siklus II.

Beberapa tehnik yang digunakan untuk mendapatkan data meliputi: Dokumentasi, digunakan untuk menggali informasi tentang prestasi awal sebagai nilai pra siklus, merekam/ mengambil foto sebagai dokumen proses kegiatan belajar- mengajar; Angket, digunakan untuk memeroleh data tentang kondisi subyek penelitian yang mencerminkan motivasi belajar, seperti: kepemilikan bahan ajar, rutinitas belajar, dan lain lain; Observasi, digunakan untuk menggali informasi tentang motivasi belajar yang ditunjukkan pada keaktifan siswa dalam kerja kelompok, juga data tentang kemampuan mengajar guru; Test, digunakan untuk menggali informasi tentang hasil belajar siswa selama proses penelitian tindakan kelas dengan menggunakan instrumen berupa soal, yang dilakukan pada akhir siklus.

Tehnik analisa data kuantitatif digunakan untuk mengukur: Pertama, tingkat motivasi subyek penelitian pada pra siklus dengan rumus:

Skor siswa $=\frac{\text { skor yang diperoleh }}{\text { skor maksimal }} \times 100$

Kriteria tingkat motivasi awal/ pra siklus mengikuti pembelajaran geografi adalah sebagai berikut: a) motivasi belajar sangat tinggi jika skor mencapai $>80$, b) motivasi belajar tinggi jika skor $60-80$, c) motivasi belajar sedang jika skor 40-59, dan d) motivasinya rendah jika skor $<40$.

Kedua, motivasi belajar siswa pada saat pelaksanaan tindakan diukur dari keaktifannya mengikuti pembelajaran menggunakan lembar observasi. Siswa yang on task (terlibat aktif dalam kegiatan belajar) dan siswa yang off task (tidak aktif dalam kegiatan belajar pada setiap siklus/ setiap periode tertentu. Jika data menunjukkan $>80 \%$ tergolong adekuat/ memadai dan $>90 \%$ tergolong bagus. (Daniel Muij \& David Reynolds, 2008: 385). Ketiga, hasil belajar siswa diukur dari penilaian harian, jika hasil penilaian harian $>$ KKM dengan skor 68 tergolong tuntas dan $<$ dari 68 tergolong tidak tuntas.

\section{Hasil dan Pembahasan}

Informasi yang dapat digali dari kondisi pra siklus terkait motivasi belajar geografi subyek penelitian adalah: 3\% motivasi sangat tinggi, $58 \%$ tinggi, 39\% motivasi sedang, sedangkan informasi tentang hasil belajar, rata-rata penilaian harian sebesar 59,23 (rata-rata dibawah KKM). Hal ini menunjukkan hasil belajar yang kurang, menjadi masukan bagi guru untuk menggunakan metode mengajar yang tepat, agar dapat memberikan motivasi kepada siswa untuk lebih berprestasi. (Sunarti, 2008: 2).

Tahap perencanaan kegiatan penelitian tindakan kelas dilakukan: 1). membuat administrasi pembelajaran seperti: Rencana Pelaksanaan Pembelajaran, Lembar Kerja Siswa (LKS), materi ajar, media pembelajaran, lembar observasi/ lembar pengamatan proses belajar siswa dan proses mengajar guru, instrumen angket motivasi belajar siswa, instrumen penilaian harian, 2). Penggalian informasi kondisi motivasi belajar siswa dan hasil belajar siswa pra siklus, yang dilaksanakan pada bulan Juli.

Pelaksanaan penelitian tindakan kelas setiap siklus terdiri dari dua pertemuan untuk kegiatan pembelajaran dan diakhiri dengan penilaian harian pada akhir siklus.

Pelaksanaan pembelajaran pertemuan pertama dilaksanakan dengan menerapkan Model Pembelajaran Kooperatif tipe Group Investigation/ Investigasi Kelompok meliputi: Pendahuluan diwali dengan salam pembuka dilanjutkan presensi siswa, guru memantau ketertiban dan kesiapan siswa untuk melaksanakan pembelajaran, guru menyampaikan apersepsi, guru menyampaikan materi ajar; pada kegiatan inti meliputi: a) observing/ mengamati: siswa mencermati materi pembelajaran, guru membagi kelompok belajar, guru memberikan tugas investigasi sesuai dengan topik yang dipilih; b) questioning/ menanya: siswa dipersilahkan bertanya hal yang belum jelas; c) experimenting/ mengumpulkan informasi: siswa menggali informasi dari berbagai sumber, berdiskusi, mengklarifikasi dan mensintesis semua gagasan; d) associating/ mengasosiasi: setiap anggota kelompok menyiapkan laporan akhir yang akan digunakan sebagai panduan presentasi; e) mengomunikasikan (communicating): presentasi kelompok, Guru memberikan penguatan materi berdasarkan hasil presentasi. f) Kegiatan Penutup evaluasi pembelajaran yang dilakukakan guru dan siswa. 
Dalam pelaksanaan pembelajaran, dihadirkan observer yang bertugas mengamati aktivitas guru mengajar dan aktivitas siswa belajar. Hasil observasi adalah: RPP sudah baik, kegiatan pembelajaran guru mencapai skor 76 , tergolong baik.
Hasil observasi motivasi belajar siswa diperoleh nilai/ skor rata-rata 88,2 tergolong adekuat / memenuhi syarat/ memadai. (Kamus Besar Bahasa Indonesia), seperti terlihat pada tabel 1 berikut.

Tabel 1. Skor Motivasi Belajar Pertemuan 1

\begin{tabular}{cccccccccc}
\hline Indikator & $\begin{array}{l}\text { Nilai } \\
\text { Kel.I }\end{array}$ & $\begin{array}{l}\text { Nilai } \\
\text { Kel.II }\end{array}$ & $\begin{array}{l}\text { Nilai } \\
\text { Kel.III }\end{array}$ & $\begin{array}{l}\text { Nilai } \\
\text { Kel.IV }\end{array}$ & $\begin{array}{l}\text { Nilai } \\
\text { Kel.V }\end{array}$ & $\begin{array}{l}\text { Nilai } \\
\text { Kel.VI }\end{array}$ & $\begin{array}{l}\text { Nilai } \\
\text { Kel.VII }\end{array}$ & $\begin{array}{l}\text { Nilai } \\
\text { Kel.VIII }\end{array}$ & $\begin{array}{c}\text { Kilai } \\
\text { Kel.IX }\end{array}$ \\
\hline $\begin{array}{c}\text { 1. Ketepatan } \\
\text { waktu kerja } \\
\text { kelompok }\end{array}$ & 3 & 4 & 4 & 3 & 4 & 3 & 3 & 3 & 4 \\
\hline $\begin{array}{c}\text { 2. Kerja sama } \\
\text { kelompok }\end{array}$ & 3 & 3 & 4 & 3 & 3 & 3 & 4 & 3 & 4 \\
\hline $\begin{array}{c}\text { 3. Kelengkapan } \\
\text { hasil kerja } \\
\text { kelompok }\end{array}$ & 4 & 4 & 4 & 4 & 4 & 3 & 3 & 3 & 4 \\
\hline $\begin{array}{c}\text { 4. Efektivitas } \\
\text { presentasi }\end{array}$ & 4 & 3 & 3 & 4 & 4 & 4 & 3 & 4 & 3 \\
\hline Skor & 87,5 & 87,5 & 93,5 & 87,5 & 93,8 & 81,3 & 81,3 & 81,3 & 93,8 \\
\hline $\begin{array}{c}\text { Rata-rata Skor } \\
\text { Pertemuan 1 }\end{array}$ & & & & 78,2 & & & \\
\hline
\end{tabular}

Hasil dari tahap Refleksi antara lain: komponen perlu ditingkatkan seperti media pembelajaran yang lebih interaktif, sedangkan yang terkait motivasi belajar siswa antara lain: guru lebih meningkatkan pengawasan dan pemantauan kelompok-kelompok belajar siswa, misalnya dengan berkeliling kelas, agar siswa lebih termotivasi belajar.

Pertemuan 2 Siklus I meliputi: tahap Perencanaan kegiatan yang dilakukan adalah memperbaiki RPP sesuai masukan observer; tahap Pelaksanaan, guru melaksanakan kegiatan pembelajaran dengan langkah- langkahnya seperti pada pertemuan 1. Pada tahap observasi observer mengamati aktivitas guru mengajar dan motivasi belajar siswa dalam mengikuti proses pembelajaran.

Hasil observasi pertemuan ke-2 sebagai berikut: kegiatan pembelajaran guru diperoleh nilai/ skor 78, tergolong baik. Hasil observasi terkait motivasi belajar diperoleh skor rata- rata 89 tergolong adekuat/ memadai, seperti terlihat pada tabel 2 berikut.

Tabel 2. Skor Motivasi Belajar Pertemuan 2

\begin{tabular}{|c|c|c|c|c|c|c|c|c|c|}
\hline Indikator & $\begin{array}{l}\text { Nilai } \\
\text { Kel.I }\end{array}$ & $\begin{array}{l}\text { Nilai } \\
\text { Kel.II }\end{array}$ & $\begin{array}{l}\text { Nilai } \\
\text { Kel.III }\end{array}$ & $\begin{array}{l}\text { Nilai } \\
\text { Kel.IV }\end{array}$ & $\begin{array}{l}\text { Nilai } \\
\text { Kel.V }\end{array}$ & $\begin{array}{l}\text { Nilai } \\
\text { Kel.VI }\end{array}$ & $\begin{array}{l}\text { Nilai } \\
\text { Kel.VII }\end{array}$ & $\begin{array}{l}\text { Nilai } \\
\text { Kel.VIII }\end{array}$ & $\begin{array}{l}\text { Nilai } \\
\text { Kel.IX }\end{array}$ \\
\hline $\begin{array}{l}\text { 1. Ketepatan } \\
\text { waktu kerja } \\
\text { kelompok }\end{array}$ & 3 & 3 & 3 & 3 & 3 & 4 & 3 & 3 & 3 \\
\hline $\begin{array}{l}\text { 2. Kerja sama } \\
\text { kelompok }\end{array}$ & 4 & 3 & 4 & 3 & 3 & 4 & 4 & 3 & 4 \\
\hline $\begin{array}{l}\text { 3. Kelengkapan } \\
\text { hasil kerja } \\
\text { kelompok }\end{array}$ & 4 & 4 & 4 & 4 & 4 & 4 & 4 & 4 & 4 \\
\hline $\begin{array}{l}\text { 4. Efektivitas } \\
\text { presentasi }\end{array}$ & 4 & 3 & 4 & 4 & 3 & 3 & 3 & 4 & 4 \\
\hline Skor & 93,8 & 81,3 & 93,5 & 87,5 & 81,3 & 93,5 & 87,5 & 87,5 & 93,8 \\
\hline $\begin{array}{l}\text { Rata-rata Skor } \\
\text { Pertemuan } 1\end{array}$ & \multicolumn{9}{|c|}{89,0} \\
\hline
\end{tabular}

Hasil pada tahap refleksi antara lain: proses kegiatan mengajar guru saat pembelajaran sudah mengalami peningkatan skor, dari skor 76 di pertemuan pertama menjadi 78 pada pertemuan kedua.

Sebagai rekomendasi, perlu peningkatan menggunakan media pembelajaran yang interaktif, bisa berkolaboarsi dengan guru yunior yang kemampuan IT nya lebih bagus,

perlu peningkatan pengelolaan kelas saat kegiatan pembelajaran, misalnya memantau proses kerja kelompok dengan berkeliling kelas, agar siswa lebih termotivasi untuk melaksanakan proses belajar secara maksimal. 
Pertemuan ke-3 dari siklus I dilaksanakan penilaian harian, meliputi: 1). Tahap Perencanaan dilakukan penggandaan instrumen penilaian, menyiapkan lembar jawaban, menyiapkan daftar hadir; 2). Pelaksanaan ulangan harian/ penilaian harian. Satu siswa tidak masuk, hasil penilaian harian siklus I ketuntasan belajar mencapai $80 \%$ seperti tertera pada tabel 3 berikut.

Tabel 3. Hasil Penilaian Harian Siklus I

\begin{tabular}{clc}
\hline No & \multicolumn{1}{c}{ Kriteria } & Jumlah \\
\hline 1. & Tuntas & 24 \\
2. & Tidak Tuntas & 6 \\
\hline & Persentase & $80,00 \%$ \\
\hline
\end{tabular}

Pada tahap Refleksi dikemukakan bahwa: meskipun hasil penilaian harian pada siklus I sudah mencapai ketuntasan belajar 80\%, namun harus ditingkatkan lebih baik lagi. Tindak lanjutnya antara lain : guru memberikan remidial teaching kepada beberapa siswa yang belum tuntas.

Siklus II meliputi pertemuan 4 dan pertemuan 5 dilakukan kegiatan pembelajaran dan pertemuan 6 dilakukan penilaian harian siklus II.

Pertemuan 4 dilaksanakan meliputi: tahap perencanaan yang dilakukan adalah menyiapkan administrasi pembelajaran; tahap pelaksanaan, guru melakukan kegiatan pembelajaran dengan langkah- langkah pembelajaran sebelumnya. Pada Tahap Observasi diperoleh skor pengamatann proses pembelajaran guru sebesar 79, tergolong baik. Hasil observasi kegiatan belajar siswa diperoleh skor 93 tergolong bagus seperti terlihat pada tabel 4 berikut.

Tabel 4. Skor Motivasi Belajar Pertemuan 4

\begin{tabular}{|c|c|c|c|c|c|c|c|c|c|}
\hline Indikator & $\begin{array}{l}\text { Nilai } \\
\text { Kel.I }\end{array}$ & $\begin{array}{l}\text { Nilai } \\
\text { Kel.II }\end{array}$ & $\begin{array}{l}\text { Nilai } \\
\text { Kel.III }\end{array}$ & $\begin{array}{l}\text { Nilai } \\
\text { Kel.IV }\end{array}$ & $\begin{array}{l}\text { Nilai } \\
\text { Kel.V }\end{array}$ & $\begin{array}{l}\text { Nilai } \\
\text { Kel.VI }\end{array}$ & $\begin{array}{l}\text { Nilai } \\
\text { Kel.VII }\end{array}$ & $\begin{array}{l}\text { Nilai } \\
\text { Kel.VIII }\end{array}$ & $\begin{array}{l}\text { Nilai } \\
\text { Kel.IX }\end{array}$ \\
\hline $\begin{array}{l}\text { 1. Ketepatan } \\
\text { waktu kerja } \\
\text { kelompok }\end{array}$ & 4 & 3 & 4 & 3 & 3 & 3 & 4 & 4 & 4 \\
\hline $\begin{array}{l}\text { 2. Kerja sama } \\
\text { kelompok }\end{array}$ & 4 & 4 & 4 & 4 & 4 & 4 & 4 & 3 & 4 \\
\hline $\begin{array}{l}\text { 3. Kelengkapan } \\
\text { hasil kerja } \\
\text { kelompok }\end{array}$ & 4 & 4 & 4 & 4 & 3 & 3 & 4 & 4 & 4 \\
\hline $\begin{array}{l}\text { 4. Efektivitas } \\
\text { presentasi }\end{array}$ & 3 & 3 & 4 & 4 & 4 & 3 & 3 & 4 & 4 \\
\hline Skor & 93,8 & 93,8 & 100 & 93,8 & 87,5 & 81,3 & 93,8 & 93,8 & 100 \\
\hline $\begin{array}{c}\text { Rata-rata Skor } \\
\text { Pertemuan } 1\end{array}$ & \multicolumn{9}{|c|}{93,0} \\
\hline
\end{tabular}

Hasil Refleksi: Pembelajaran guru sudah baik, namun media yang digunakan perlu ditingkatkan lebih interaktif.

Pertemuan 5 dilaksanakan dengan langkahlangkahnya sebagai berikut: tahap perencanaan guru menyiapkan administrasi pembelajaran; tahap pelaksanaan, guru melakukan kegiatan pembelajaran dengan langkah- langkah seperti pembelajaran sebelumnya.

Nilai/Skor hasil Observasi kegiatan pembelajaran guru sebesar 79, tergolong baik. Hasil observasi motivasi belajar siswa sebesar 94,5 tergolong bagus, seperti terlihat pada tabel 5 berikut.

Tabel 5. Skor Motivasi Belajar Pertemuan 5

\begin{tabular}{|c|c|c|c|c|c|c|c|c|c|}
\hline Indikator & $\begin{array}{l}\text { Nilai } \\
\text { Kel.I }\end{array}$ & $\begin{array}{l}\text { Nilai } \\
\text { Kel.II } \\
\end{array}$ & $\begin{array}{l}\text { Nilai } \\
\text { Kel.III } \\
\end{array}$ & $\begin{array}{l}\text { Nilai } \\
\text { Kel.IV }\end{array}$ & $\begin{array}{l}\text { Nilai } \\
\text { Kel.V }\end{array}$ & $\begin{array}{l}\text { Nilai } \\
\text { Kel.VI } \\
\end{array}$ & $\begin{array}{l}\text { Nilai } \\
\text { Kel.VII }\end{array}$ & $\begin{array}{l}\text { Nilai } \\
\text { Kel.VIII } \\
\end{array}$ & $\begin{array}{l}\text { Nilai } \\
\text { Kel.IX }\end{array}$ \\
\hline $\begin{array}{l}\text { 1. Ketepatan } \\
\text { waktu kerja } \\
\text { kelompok }\end{array}$ & 4 & 4 & 4 & 4 & 3 & 3 & 4 & 4 & 4 \\
\hline 2. Kerja sama & 4 & 4 & 4 & 4 & 4 & 4 & 4 & 3 & 4 \\
\hline $\begin{array}{l}\text { 3. Kelengkapan } \\
\text { hasil kerja } \\
\text { kelompok }\end{array}$ & 4 & 4 & 4 & 4 & 3 & 3 & 4 & 4 & 4 \\
\hline $\begin{array}{l}\text { 4. Efektivitas } \\
\text { presentasi }\end{array}$ & 4 & 3 & 4 & 3 & 4 & 4 & 3 & 4 & 4 \\
\hline Skor & 100 & 93,8 & 100 & 93,8 & 87,5 & 87,5 & 93,8 & 93,8 & 100 \\
\hline $\begin{array}{c}\text { Rata- rata Skor } \\
\text { Pertemuan } 1\end{array}$ & \multicolumn{9}{|c|}{94,5} \\
\hline
\end{tabular}


Hasil Refleksi: terdapat satu siswa yang tidak aktif dalam tiga kali pertemuan. Anak tersebut dalam pembelajaran biasanya kurang berkonsentrasi. Inilah salah satu kelemahan penggunaan teknik kooperatif yang disebut dengan "free-rider effect" (efek "pendompleng") yaitu adanya murid tertentu yang kurang aktif dalam kegiatan pembelajaran dan membiarkan orang lain melakukan tugas pembelajaran, baik karena merasa tidak bisa atau tidak mau. (Daniel Muijs dan David Reynolds, 2008: 77)

Kenyataan di lapangan tentang free-rider effect menjadi tantangan bagi guru untuk dapat mengelola kejadian yang negatif tersebut secara konstruktif (David dkk, 2010: 135).

Pertemuan 6 adalah penilaian harian siklus II yang dilaksanakan meliputi: tahap perencanaan yaitu menyiapkan penggandaan instrumen penilaian, lembar jawaban, daftar hadir, dll; tahap pelaksanaan, yaitu pelaksanaan penilaian harian; kegiatan penutup: mengumpulkan lembar jawab dan soalnya.

Tahap Observasi, guru mengoreksi hasil evaluasi sebelum pertemuan selanjutnya. Hasil penilaian harian siklus II dapat dijelaskan pada table 6 berikut.

Tabel 6. Hasil Penilaian Harian Siklus II

\begin{tabular}{clc}
\hline No & Kriteria & Jumlah \\
\hline 1. & Tuntas & 28 \\
2. & Tidak Tuntas & 3 \\
\hline & Prosentase & $90,32 \%$ \\
\hline
\end{tabular}

Dari refleksi diketahui bahwa hasil belajar siswa mengalami peningkatan, namun guru tetap harus meningkatkan kualitas proses pembelajarannya agar dapat meningkatkan motivasi belajar siswa, motivasi belajar siswa yang tinggi diharapkan dapat meningkatkan hasil belajar, baik peningkatan nilai reratanya maupun ketuntasannya.

Penerapan Model Pembelajaran Kooperatif Tipe Group Investigation dapat meningkatkan motivasi belajar dan hasil belajar siswa seperti dijelaskan berikut.

\section{Motivasi belajar siswa}

Tabel 7. Skor Motivasi Belajar Siswa

\begin{tabular}{cccc}
\hline Siklus & $\begin{array}{c}\text { Perte- } \\
\text { muan }\end{array}$ & $\begin{array}{c}\text { Skor } \\
\text { Motivasi } \\
\text { belajar }\end{array}$ & $\begin{array}{c}\text { Rata- rata } \\
\text { skor per } \\
\text { siklus }\end{array}$ \\
\hline \multirow{2}{*}{ I } & 1 & $88,2 \%$ & 88,60 \\
\hline \multirow{2}{*}{ II } & 2 & $89,0 \%$ & 93,75 \\
\hline
\end{tabular}

Motivasi belajar siswa dalam proses pembelajaran mengalami peningkatan dari siklus I ke siklus II, yaitu dari $88,60 \%$ (tergolong adekuat/ memadai), meningkat menjadi 93,75\% (tergolong bagus). Grafiknya terlihat pada gambar 2 berikut.

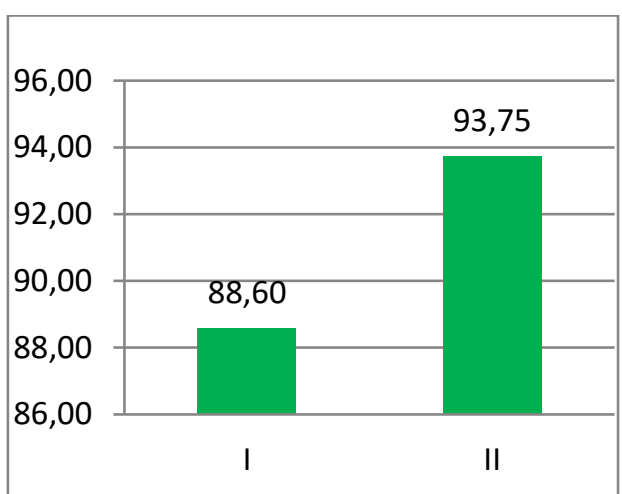

Gambar 2. Peningkatan Motivasi Belajar Siswa Siklus I dan Siklus II

\section{Hasil Belajar Siswa}

Peningkatan ketuntasan belajar mengalami kenaikan dari sebelum tindakan dan setelah tindakan, seperti tertera pada tabel 8 berikut.

Tabel 8. Hasil Penilaian Harian

\begin{tabular}{ccccc}
\hline No & Kriteria & $\begin{array}{c}\text { Pra } \\
\text { Siklus }\end{array}$ & $\begin{array}{c}\text { Siklus } \\
\text { I }\end{array}$ & $\begin{array}{c}\text { Siklus } \\
\text { II }\end{array}$ \\
\hline 1. & Tuntas & 9 & 24 & 28 \\
\hline 2. & Tidak Tuntas & 22 & 6 & 3 \\
\hline & $\begin{array}{l}\text { Persentase } \\
\text { ketuntasan }\end{array}$ & $\begin{array}{c}29,03 \\
\%\end{array}$ & $\begin{array}{c}80,00 \\
\%\end{array}$ & $\begin{array}{c}90,32 \\
\%\end{array}$ \\
& & & & \\
\hline
\end{tabular}

Sebelum tindakan, ketuntasan belajar siswa mencapai 29,03\% (9 siswa tuntas). Setelah tindakan mengalami peningkatan menjadi $80,00 \%$ (24 siswa tuntas) pada siklus I dan $90,32 \%$ (28 siswa tuntas) pada siklus II.

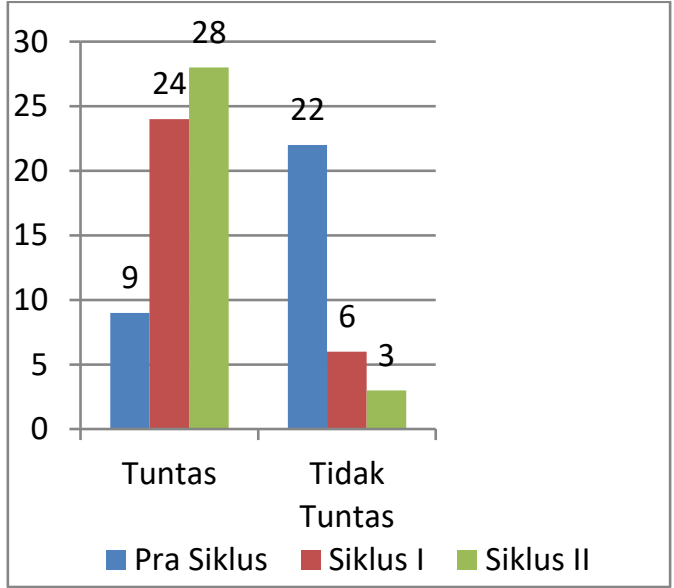

Gambar 3. Peningkatan Ketuntasan Belajar Siklus I dan Siklus II 
Hal ini menunjukkan bahwa belajar kelompok jauh lebih baik dari pada belajar sendiri, karena terjadi tutor teman sebaya proses penguasaan materi lebih cepat, sehingga memungkinkan hasil belajar lebih bagus. Disamping itu belajar kelompok melatih membentuk organisasi, saling menghargai pendapat orang lain, melatih ketrampilan berkomunikasi, dan melatih toleransi. (Zainuddin, 2017: 326)

\section{Simpulan dan Saran}

Hasil Penelitian Tindakan Kelas dengan Pengunaan Model Pembelajaran Kooperatif tipe Group Investigation pada Pelajaran Geografi di kelas XII IPS 2 SMA Negeri 1 Banguntapan Tahun Ajaran 2019/2020 menghasilkan kesimpulan sebagai berikut:

Serangkaian Penerapan Model Pembelajaran Kooperatif Tipe Group Investigation dalam pembelajaran Geografi meliputi meliputi tahap : perencanaan, pelaksanaan, observasi dan refleksi. Pada tahap perencanaan, guru membuat administrasi pembelajaran yang diperlukan. Pada tahap pelaksanaan, guru melaksanakan kegiatan pembelajaran dengan langkah- langkahnya meliputi: 1) Mengidentifikasi topik dan mengatur murid ke dalam beberapa kelompok secara heterogen, 2). Merencanakan Tugas yang akan dipelajari dan pembagian tugas dalam kelompok; 3). Melaksanakan investigasi, siswa secara berkelompok menggali informasi dari berbagai sumber; 4). Menyiapkan laporan akhir sebagai bahan diskusi; 5) Masing- masing kelompok secara bergiliran mempresentasikan hasil diskusi; 6) Evaluasi.

Penerapan Model Pembelajaran Kooperatif tipe Group Investigation mampu meningkatkan motivasi belajar siswa dari siklus I sebesar $88,60 \%$ (tergolong adekuat/ memadai), meningkat menjadi $93,75 \%$ (tergolong bagus) pada siklus II

Penerapan Model Pembelajaran Kooperatif tipe Group Investigation mampu meningkatkan ketuntasan hasil belajar siswa, dari siklus I sebesar $80,00 \%$ menjadi $90,32 \%$ pada siklus II.

Sebagai saran, guru sebaiknya selalu mencoba menggunakan model pembelajaran yang bervariasi agar dapat meningkatkan motivasi siswa dalam mengikuti kegiatan pembelajaran sehingga mampu mencapai hasil belajar yang lebih baik. Meskipun begitu didalam kelas selalu ada siswa yang kurang aktif dalam kegiatan pembelajaran, untuk sebaiknya dikelola secara positif untuk membantu mereka mencapai hasil belajar yang lebih baik.

\section{Daftar Pustaka}

. (2019). Silabus Mata Pelajaran Geografi SMA. Tahun 2019.

Agus Wasisto. (2018). Cara Mudah Melakukan Penelitian Tindakan Kelas. Yogyakarta: Graha Cendikia.

Bobbi, dePorter, dkk. (2010). Quantum Teaching, Mempraktekkan Quantum Teaching di Ruang- ruang Kelas. Bandung: Mizan Pustaka.

Daniel Muijs \& David Reynolds. (2008). Effective Teaching Teori dan Aplikasi. Edisi kedua. Yogyakarta: Pustaka Pelajar. Terjemahan.

Djamarah, Syaiful Bahri. (2000). Guru dan Anak Didik Dalam Interaksi Edukatif. Jakarta: PT Rineka Cipta.

Mimin Haryati. (2008). Model dan Tehnik Penilaian Pada Tingkat Satuan Pendidikan. Jakarta: Gaung Persada Press.

Mulyasa. (2008). Standar Kompetensi dan Sertifikasi Guru. Bandung: Remaja Rosdakarya.

Slavin, Robert. (2009). Cooperative Learing, Teori, Riset, dan Praktik. Bandung: Nusa Media.

Stevani. (2016). Analisis pengaruh Motivasi Belajar Terhadap Hasil Belajar Ekonomi Siswa Kelas X SMA N 5 Padang. Journal of Economic and Economic Education, 4(2).

Sunarti. (2008). Sistem Penilaian Berbasis Kompetensi. Yogyakarta: Pasca Sarjana Universitas PGRI.

Suprihatiningrum, Jamil. (2014). Strategi Pembelajaran, Teori dan Aplikasi. Yogyakarta: Ar- Ruzz Media.

Suranten. (2019). Peningkatan Prestasi Belajar dan Respon Siswa Materi SPLTV Menggunakan Model Pembelajaran Group Investigation pada Siswa Kelas X MIPA 4 SMA $N 1$ Banguntapan. Laporan PTK.

Syukriyati, Alfi. (2016). Upaya Meningkatkan Hasil Belajar Mata Pelajaran IPS Melalui Metode Group Investigation SMP 3 Imogiri. Ideguru: Jurnal Karya Ilmiah Guru, 1(1), 40-64.

Widarwati. (2009). Strategi dan Metode Pembelajaran. Makalah disampaikan pada Pendidikan dan Pelatihan Guru Geografi SMA Jenjang Dasar. Malang: Pusat Pengembangan dan Pemberdayaan Pendidik dan Tenaga Kependidikan.

Zainuddin. (2017). The Best Teachers. 200 Dalil Motivasi untuk Menjadi Guru Terbaik \& Sukses. Jakarta: Indeks. 